\title{
Introdução ao Direito Romano das Obrigações, aplicado ao Direito Civil.
}

\author{
Alexandre Augusto de Castro Corrêa \\ Professor de Direito Romano da Faculdade de Direito \\ da Universidade de São Paulo.
}

A vida social, em sua complexidade, impõe aos homens a divisão do trabalho, tanto mais acentuada quanto maior o grau de civilização dos povos. Sob o aspecto econômico, o homem, não podendo bastar-se, integralmente, a si próprio, entra, necessàriamente, em relações de trocas com os semelhantes, dando suas sobras a fim de obter o de que necessita.

A permuta, neste sentido, cujo mais simples tipo é a troca de coisa por coisa ("do ut des"), constitui a base das relações econômicas entre os homens.

Na forma imediata a troca é à vista assim como também a compra e venda primitiva, razão pela qual o conhecido texto de Paulo no Digesto $(18,1,1$,$) diz: "Origo$ emendi vendendique a permutationibus coepit". A venda vem da permuta: dou no mercado minhas batatas, por ex., para receber e levar comigo sapatos e meias. As trocas, porém, podem efetuar-se tendo em vista o futuro e antecipando necessidades futuras: dou hoje café para receber roupas daqui a três meses, quando meus filhos precisarem ir à escola.

Aqui, em lugar da troca imediata das mercadorias, atendendo às necessidades dos interessados, um dêles ficou devedor do outro, isto é, ficou sujeito para com êle a efe- 
tuar um pagamento futuro. Noutras palavras, ficou obrigado.

Quem recebeu prestação antecipada obteve vantagem econômica, enriqueceu, portanto. Como porém a intenção de quem deu alguma coisa era receber, embora no futuro, outra coisa em troca, surgiu, para quem recebeu, o dever de cumprir o prometido, efetuando, no tempo futuro ajustado, a contraprestação combinada.

Eis aí como os contratos são uma primeira fonte ou causa geradora das obrigações. A noção, porém, de obrigação, deve ser aqui enunciada e para tanto podemos muito bem valer-nos do seguinte texto: "Obligatio est juris vinculum quo necessitate adstringimur alicujus solvendae rei secundum nostrae civitatis jura". ${ }^{1}$

Analisemos semelhante definição: a "obligatio" é um “juris vinculum", isto é, vínculo de direito. Pelo vínculo, aliás de natureza abstrata, nasce a relaçâo de débito $e$ crédito entre duas pessoas.

Em nossos anteriores exemplos, quem deu o café em troca de roupas, a serem entregues em prazo futuro, adquiriu contra a outra parte o direito isto é, um poder especialmente garantido pela autoridade pública; a saber, o poder de exigir no prazo ajustado o cumprimento da promessa, tendo interêsse econômico, isto é, valor em dinheiro para o credor. E para o promitente surgiu com tôda evidência e em razão mesmo da promessa o dever de cumpri-la, em benefício do credor.

"Promessa é divida" diz, aliás, o provérbio, resumindo a idéia do dever inerente ao conceito de obrigação.

Em conseqüência dessa promessa minha vontade fica limitada ou vinculada no sentido de eu poder fazer tudo quanto quiser menos deixar, impunemente, de cumprir o prometido. Logo o dever representa uma lei, restringindo justificadamente a liberdade de minha vontade em bene-

1. Institutas, 3,13 , pr. 
fício doutra pessoa, que confiou ou acreditou em mim, chamando-se, por isso mesmo, credor.

E credor quem, tendo confiado ou acreditado ("bona fides", boa fé) na promessa alheia, "faz jus" ou tem direito ao cumprimento da mesma. É devedor quem, em face duma lei de caráter essencialmente moral, está sujeito a efetuar um ato, por exemplo prestar serviços, a outrem. (c.c. b. ${ }^{\circ}$, art. 1216).

Seria, "com efeito, impossível a vida econômica, o comércio por exemplo, se os homens devessem desconfiar uns dos outros," não dando crédito a ninguém, isto é, não acreditando no cumprimento futuro das promessas presentes. Gostấria alguém de ser burlado ou ilaqueado em sua boa fé ou confiança? Quem não se sente indignado quando, pơrventura, sofre aś conseqüências da desonestidade dum devedor o qual, consumindo o nosso dinheiro, não o restitui, violando a promessa feita? Todos aceitam, por conseguinte, a idéia do dever como essencial ao bom andamento dos negócios entre os homens. A fraude e o estelionato são, inclusive, punidos comó çrimes.

Assim, o primeiro elemento da noçã̉o de obriğação é esta idéia de dever unindo credor e devedor.

O têrmo latino, aliás, "obligatio", considerado etimològicamente, revela claramente a idéia de "ligatio" ou "vinculum" entre duas ou mais pessoas. Além disso a preposição "ob", "em razão de", "por causa de", indica, também, a necessária causa jurídica duma "ligatio."

Ora, os contratos, como já sabemos, são uma das fontes ou causas geradoras das obrigações. As outras são, aliás, comd yeremos, o "delito" (v.g. o furto), o quase delito (v.g. "positum et suspensum") e o quase contrato (v.g. "negotiorum gestio") segundo classificação das fontes seguida modernamente pelo Código Civil Francês. ${ }^{2}$

Voltemos, porém, à nossa definição: o "vinculum" no qual consiste a obrigação é jurídico ("juris") pelo fato

2. Ver C.C.b. ${ }^{\circ}$, art. 1331 e segs. - Gestão de Negócios. 
de acarretar a responsabilidade ("obligatio"; "Haftung", dos romanistas alemães) do devedor. Com efeito, a ordem jurídica não pode admitir que tendo prometido, por exemplo, dar, fazer ou prestar alguma coisa de valor econômico em benefício do credor, deixe o devedor impunemente de cumprir sua promessa, burlando, assim, a justimente de qualquer colaboração do devedor.

Assim, suponhamos um "chirographum" ou confissão de dívida. Entregando o documento ao credor de quem recebo dinheiro emprestado consenti, digamos, em apor minha assinatura como condição para obter o empréstimo desejado (c.G. art. 1;505 e ss.). Intimamente, porém, sem nada dizer ao credor, posso ter decidido não honrar minha firma. Procedo, como se diz, com "reserva mental", deslealmente e de má fé. Se o credor conhecesse minha disposição intima provàvelmente nada me teria emprestado. justo, pois, que êle possa exigir de mim, inclusive contra minha vontade interior em contrário, o cumprimento de minha promessa. Nisto, exatamente consiste, aliás, o caráter "jurídico" da obrigação. Não cumprindo sua obrigação, diz nosso Código Civil (art. 1056), no tempo e pelo modo. devidos, responde o devedor por perdas e danos, quer dizer, a ordem jurídica põe à disposição do interessado um meio. judicial chamado "ação" e pelo qual o credor pode obter a realizaçâo ou satisfação de seu crédito, independentemente de qualquer colaboração do devedor.

Assim, chamado ao Tribunal, por ordem do juiz, para defender-se e não provando alegação nenhuma contra a reclamação do credor, poderá o devedor ser condenado, por sentença, também do juiz, a pagar e, se, apesar da condenação, resistir à sentença, deixando de efetuar o pagamento, o credor poderá ir além, querendo: poderá executar, como se diz, o devedor, isto é, poderá pràticamente pedir e obter sejam retirados ao devedor tantos bens quantos bastem para, mediante venda em hasta pública, ser satisfeito e pago o crédito do autor da demanda. 
"A todo direito" diz o Código Civil, (art. 75), "corresponde uma ação que o assegura". Esta regra é, essencialmente, romanística, pois o Direito Romano clássico só reconhecia um direito ("jus") se existisse para tutela-lo a competente "actio".

E a aç̃o ("actio") foi, mesmo, admiràvelmente deinida pelo jurisconsulto CELSo, em íntima relação com o Direito das Obrigações, como "jus persequendi in judicio quod sibi debetur". Em outras palavras, onde não houver "actio", isto é, onde não houver meios destinados a coagir o devedor ao cumprimento de sua obrigação, não haverá "obrigação" em sentido jurídico. Salvo o caso excepcional das obrigações chamadas naturais (v.g. a obrigação resultante de divida prescrita; em Direito Romano as obrigações contraídas entre o "pater famílias" e o "filius" debaixo de seu poder, as obrigações entre o "servus" e o "dominus", etc.), as obrigações juridicas são, em regra, civis, isto é, munidas de ações em benefício e à disposição do credor contra o devedor insolvente.

As obrigações, em sentido jurídico, são assim, uma verdadeira espécie das obrigações em sentido moral, enquanto estas últimas não importam e as primeiras, pelo contrário, importam em responsabilidade do devedor. $\mathrm{O}$ dever de caridade é puramente moral, não podendo o mendigo, por exemplo, responsabilizar-me por não the ter eu dado a esmola solicitada. Minha recusa em ajudar ao próximo não acarreta para mim nenhuma sanção além daquela contida em minha consciência e manifestando-se, por exemplo, sob a forma de eventual remorso. A autoridade do Estado não tem podêres, para impor-me, coercitivamente, e contra minha vontade, a obediência ao dever de caridade e de solidariedade humana.

Pode, entretanto, conforme a época histórica, haver maior entrosamento, por assim dizer, entre Moral, Religião e Direito, tal como acontece na Constituição de Justiniano: "Christiani quibus verus cultus est adjuvare pauperes et 
in necessitate positos" impondo como dever jurídico, externamente sancionado, portanto, a obrigação de ajudar aos pobres.

Em nossos dias, porém, ainda inspirados por orientação individualista não há o dever legal ou jurídico da caridade. E por isso a contraposição é nitida hoje entre êsse dever, essencialmente moral e religioso dum lado e do outro o dever jurídico de restituir uma coisa que nos foi, digamos, emprestada por comodato ou mútuo. (c.c. b. ${ }^{\circ}$, arts. 1256 e ss, 1248 e ss.).

Se recebi dinheiro emprestado sob a condição, por mim aceita, de restituir, em certo tempo ou quando o credor pedir, quantia igual à recebida, houve o contrato de mútuo, isto é, contraiu-se uma obrigação jurídica. E aqui a situação do devedor é característica: tornando-se inadimplente, isto é, deixando de pagar no tempo e segundo o modo convencionados, fica o mutuário sujeito a uma ação de cobrança eventualmente proposta contra êle pelo credōor, a "condictio certae creditae pecuniae" do Direito Romano, ação de cobrança do Direito moderno, cujas conseqüências foram descritas a cima.

Através do exposto, tornam-se claras duas coisas: primeiro a distinção entre obrigação moral (gênero) e obrigação jurídica (espécie), garantida esta última pela sanção exterior e segundo as peculiaridades da definição romana de obrigação jurídica.

Acrescentaremos, entretanto, uma última observação, relativa ainda ao primeiro ponto. No exemplo do mútuo há certa intersecção entre as duas obrigações enquanto ninguém é obrigado juridicamente a emprestar coisa alguma, podendo fazê-lo "amicitiae causa", por dever de amizade e sob a influência, portanto, de sentimentos morais. Se a ajuda, porém, se fêz sob a forma de mútuo, o dever moral do credor emprestar é contrabalançado pelo dever jurídico do devedor restituir, pagando o ajustado, sob pena de sofrer as eventuais conseqüências do inadimplemento. 
Na doação também (e o mútuo "amicitiae causa" tem analogia com ela; enquanto o mutuante empresta por liberalidade) o doador pode querer enriquecer o donatário, por generosidade, por exemplo, ou por compaixão, obecedendo, portanto a impulsos de ordem moral. A doação, porém, aceita pelo donatário, transforma-se em contrato e pode ser revogada, por ingratidão, digamos do donatário, o qual pode ser juridicamente compelido a restituir o benefício recebido. (c.c., art. 1181 e ss.).

Esta intersecção apontada entre moral e direito no campo especial das obrigações parece, aliás, conexa com a teoria dos atos jurídicos a título gratuito. Na compra e venda, pelo contrário, não parece haver intersecção alguma enquanto êste contrato parece dominado pela idéia de interesses exclusiva ou predominantemente econômicos das partes contratantes e não por qualquer espírito de liberalidade.

A teoria dos atos jurídicos a título chamado oneroso parece, por isso mesmo, mais diretamente jurídica.

o Direito das Obrigações é, aliás, de conteúdo eminentemente econômico, como o das Coisas e o Sucessório. (ver c.c., art. 1543).

Daí o emprêgo tão expressivo do verbo "solvere" (pagar) indicando, na definição analisada, exatamente tal conteúdo. $\mathrm{O}$ devedor fica adstrito, em razão do vínculo obrigacional, a pagar alguma coisa, “alicujus solvendae rei", uma soma de dinheiro, é claro, antes de mais nada; de modo geral, porém, "solvere" deve ser entendido em sentido amplo como significando o cumprimento ("solutio") da obrigação assumida. Paga, assim, o mutuário, restituindo ao mutuante a quantia de dinheiro ou coisas fungíveis ao primeiro emprestadas; mas, paga, também, o empregado ("locator operarum"), prestando o trabalho convencionado com o empregador ("conductor operarum") e em razão do qual faz jus à "merces" ou salário; paga, finalmente, o mandatário quando aplica tôda a sua dili- 
gência habitual ("diligentia quam suis rebus") na execução dos atos de que foi incumbido pelo mandante ou quando lhe administra os interêsses (c. c., arts. 1300, 1288).

Não paga, pelo contrário, e é insolvente o devedor, deixando de cumprir (inadimplemento) a obrigação livremente assumida ou a que ficou sujeito por fôrça de lei (atos ilícitos, por exemplo) ou de sentença.

Passando, agora, a outra parte da definição de Justiniano, devemos, ainda, observar que além de, segundo o exposto, realçar ela o caráter jurídico do vínculo entre $o$ sujeito ativo (credor) e o sujeito passivo (devedor) da obrigação jurídica e além de mostrar a sujeição necessária do segundo ao primeiro, (graças ao sistema de ações proponíveis contra o devedor insolvente), possui ainda outro mérito: classificar, já na sua parte final, as espécies de prestações, isto é, de objetos possíveis da obrigação do devedor. Fica, êste último, com efeito, sujeito a "dare", "facere" ou "praestare" alguma coisa de valor econômico em benefício do credor e isto "secundum nostrae clvitatis jura", isto é, segundo as figuras e hipóteses previstas na lei ou, se quisermos, "na forma da lei".

"Dare" significa a prestação visando a transferência do domínio ou da posse para o credor ou a constituição dum direito real em favor dêle, mas diferente do domínio.

Assim, na compra e venda, pela qual o vendedor se obriga a transferir o domínio de certa coisa ao comprador, há prestação de “dare" (c.c. art. 1122).

Da mesma espécie é a prestação do empreiteiro quando concorre para a obra com seu trabalho e materiais também seus (c.c., art. 1237). Objeto do contrato de empreitada ("locatio conductio operis faciendi") é transferir para o dono o domínio ou propriedade do "opus" ou obra já acabada. O mútuo envolve também prestação de "dare" pois o mutuante transfere o domínio da coisa emprestada ao mutuário (c.c. art. 1257) razão pela qual não fica extinto o dever do mutuário quando êle paga com dinheiro alheio, 
não tornado propriedade ("datio") do mutuante (c.c. art. 933).

$\mathrm{Na}$ locação de serviços ("locatio conductio operarum"), no mandato e em outras figuras afins há obrigação de "facere" por parte do devedor enquanto o objeto visado pelo credor é o trabalho ou a atividade do devedor, considerados em si mesmos.

Assim, o operário ("locator operarum") obriga-se vàlidamente a trabalhar tantas horas por dia a tanto por hora; o mandatário obriga-se a praticar ("facere") os atos dêle exigidos pelo mandante. Note-se: "facere" inclui também "non facere" pois o dever de abster-se, a obrigação portanto negativa, assumida pelo devedor, pode oferecer interêsse econômico para o credor, como o "pactum de non petendo" ("remissão de dívidas", c.c., art. 1053/1055; 894) por exemplo, em razão do qual o credor se compromete a nâo exigir de seu devedor um pagamento, ao qual êle, credor, por outra causa, fazia jús.

Resta agora a parte final da definição: o devedor fica adstrito a pagar alguma coisa ("alicujus solvendae rei") "segundo o nosso (isto é, o Direito Romano ao tempo de Justiniano) Direito Civil".

Isto significa: as possiveis espécies de obrigações, sancionadas pelas respectivas ações, acham-se tôdas previstas no ordenamento juridico, vale dizer na lei e fora delas, como é lógico, não pode haver reconhecimento de outras figuras, pois do contrário a lei seria inútil, ficando também incompleta ou aberta a lista das ações. Por conseguinte, explícita ou implicitamente, qualquer espécie de obrigação jurídica, sobretudo nos países de direito codificado como o nosso, deve ter sido prevista pelo legislador. "Nulla obligatio sine lege". Fora, portanto, da lei vamos encontrar obrigações de ordem moral ou religiosa, fugindo ao objeto próprio do nosso estudo.

Significa, também, a frase o seguinte: as obrigações contratuais hão de ser conformes à lei ou aos bons costu- 
mes (c.c. art. 971), pois o interêsse econômico das partes para ser reconhecido e sancionando deve ser legitimo, isto é, conforme à lei.

A prostituta, por exemplo, pode ter interêsse econômico em receber a paga a ela prometida em razão de sua prostituição, mas não pode demandar o pagamento pois seu interêsse econômico não é legítimo, isto é, não é reconhecido pela lei por ser um interêsse econômico contrário aos bons costumes ("contra bonos mores"), isto é, ilícito e imoral.

"Para propor ou contestar uma ação" diz nosso Código (art. 76) "é necessário ter legitimo interêsse (grifo nosso) econômico ou moral."

Os contratos imorais, aliás, podem originar obrigações naturais e assim, caso a prostituta já tenha recebido a paga, gozará da "soluti retentio", e quem pagou não poderá reaver um pagamento feito para obter fim imoral (c. c. art. 971).

Outro exemplo claro é o da chamada "societas sceeleris", o contrato de sociedade feito entre criminosos. Tais pessoas, é claro, podem obrigar-se mùtuamente a combinar seus esforços ou recursos para lograr fins comuns, (c. c. art. 1363) a saber: a prática de crimes e a repartição dos eventuais produtos dêles resultantes. Tal finalidade, porém, da associação é ilícita, pois a lei penal pune os crimes e por conseguinte um ajuste entre celerados : não pode ser considerado "contrato" (c. c. art. 81). Por conseguinte, além de não poderem pleitear em juízo o cumprimento do ajuste, praticam os meliantes atos ilicitos ("delicta", "maleficia"), sujeitando-se à reparação do dano causado às vítimas, caso tenham perpetrado algum delito (c.c. art. 159).

A definição de Justiniano costuma sêr completada pelo texto de Paulo, no Digesto, 44,7 "De Oblig. et Action", 3, pr., realçando o contraste entre o Direito das Obrigações, ("jus ad rem"), criando imediatamente tão só relações jurídicas entre pessoas e o Direito das Coisas ("jus in re") 
regulando as várias formas duma pessoa exercer, de modo imediato, podêres exclusivos sôbre coisas ou objetos de direitos.

"Obligationum substantia" diz Paulo, non in eo consistit ut aliquod corpus nostrum aut servitutem nostram faciat, sed ut alium nobis obstringat ad dandum, aliquid vel faciendum vel praestandum".

A substância, portanto, ou natureza do direito das Obrigações, segundo o jurisconsulto romano, não consiste em tornar o credor titular dum direito real ("jus in re"), pois, na dogmática do Direito Romano, a qual é também a do nosso, os direitos reais se constituem por modos especiais, não se confundindo, em princípio, com as fontes dos direitos obrigacionais. Falando sôbre a tradição, modo derivado, como sabemos, de aquisição da propriedade, diz claramente nosso Código Civil, no art. 622:" "o domínio das coisas não se transfere (grifo nosso) pelos contratos antes da tradição".

Tal regra de nosso direito provém, aliás, entre outras, do seguinte texto romano: "Traditionibus et usucapionibus dominia rerum non nudis pactis transferuntur" (c.,2,3, "Depactis", 20 - DrocL.), isto é, o domínio das coisas transfere-se (entre outros modos) pela tradição e pelo usucapião e não por simples pactos. (Vêr c.c.b. ${ }^{\circ}$, arts. 550 - 553; 618 -619). Os direitos reais recaem diretamente ("jura in re") sôbre coisas, objetos de direito, e, como tais, destituídos de vontade. Visando possibilitar o uso econômico mais ou menos amplo das coisas em benefício duma pessoa, tais direitos, para seu exercício, dispensam a cooperação de terceiros, impondo mesmo a êstes últimos o dever negativo de absterem-se de qualquer ingerência ou intromissão no exercício do direito pelo seu titular. Donde dizer-se: os direitos reais são "erga omnes", exercem-se contra todos.

Os direitos obrigacionais vinculam, pelo contrário, imediatamente, duas ou mais pessôas, uma das quais (o sujeito passivo da relação, devedor, "reus debendi") fica 
adstrita a prestar determinado ato, positivo ou negativo e de valor econômico em proveito do sujeito ativo ("cre'ditor"), credor, "reus stipulandi". Os direitos obrigacionais dizem-se, por isso, "in personam" ou com sujeitos passivos determinados. Assim, posso mover uma ação de cobrança sòmente contra a pessôa ou pessôas sujeitas ao meu pedido em virtude duma relação de direito cujos sujeitos são ("jus in personam") predeterminados.

Minha demanda, portanto, por falta de legitimação passiva, como se diz, será repelida se proposta contra quem por qualquer causa não seja meu devedor.

Já na ação reivindicatória ("reivindicatio") (c.c., art. 524), proposta contra quem possuir injustamente coisa minha, o réu da demanda não será, como numa obrigação, predeterminado, mas sim quem, (pessoa indeterminada) no momento da propositura da ação, estiver possuindo.

Essa distinção, assaz importante na teoria e na prática, encontra-se, em Direito Romano, claramente exposta, entre outros, nos Comentários de Gaio (IV, 2 e 3), e nas Institutas de Justiniano (4,6 De actionibus, 1). Tem, aliás, origem processual, fundando-se nas diferentes, fórmulas elaboradas pelo pretor para propositura de ações reais e pessoais, de conformidade com a natureza diferente dos direitos em litígio.

Em conseqüência, ainda, da diferente natureza da relação jurídica, distinguindo os direitos reais dos obrigacionais ou de crédito, encontramos dois atributos dos primeiros, inexistentes nos segundos, a saber a sequela e a preferência.

Minha reivindicação, vimo-lo já, nos têrmos do art. 524 do Código Civil, pode ser proposta contra quem quer que (sujeito passivo indeterminado) possua, injustamente, coisa minha.

O direito real, de propriedade ou outro, acompanha, pois, ou segue a coisa sôbre a qual (sequela) recai, podendo exercer-se contra qualquer possuidor. 
Tão bem sentiam, aliás, os romanos esta característica dos "jura in $r e$ " a ponto de, por exceção, considerarem "res corporalis" ao domínio ou propriedade, muito embora reconhecessem os direitos em geral como "res incorporales" ou coisas incorpóreas.

O domínio para êles, enquanto direito, aderia tão completamente à coisa, seu objeto, a ponto de, sob o aspecto psicológico, ao menos, parecerem ambos inseparáveis um do outro.

Ora, a sequela, não pode, como é evidente, aparecer no Direito das Obrigações cujo objeto, em vez de coisas, são atos humanos, positivos ou negativos. Também a preferência é atributo exclusivo dos direitos reais. $O$ credor pignoratício, por exemplo, e o hipotecário gozam de preferência em concorrência com os demais credores, não enquanto credores, mas enquanto garantidos. Quer dizer: as garantias fornecidas pelo penhor e pela hipoteca (legal, convencional, judicial, pouco importa) conferem ao credor um direito real sôbre coisa alheia e assim sendo "erga omnes"; como todos os direitos reais, o penhor e a hipoteca dão a seus titulares o poder de, em caso de insolvência do devedor, pedirem a penhora e a venda em hasta pública dos bens gravados de modo a, com o produto da venda, satisfazerem os credores garantidos seus créditos integralmente, deixando aos credores não garantidos ou quirografários, como se chamam, só o remanescenie se houver.

A preferência, como é óbvio, decorre do fato dos direitos de penhor ou hipoteca (e também de anticrese c.c. art. 805 e ss.) serem reais, tendo por objeto coisas sôbre as quais de modo imediato e direto recai a garantia dos credores. Dessa forma, é claro, os credores meramente quirografários não podem concorrer com os preferenciais, justamente por não terem, enquanto quirografários, aquêle "jus in $r e$ ", pertencente aos garantidos.

A distinção é, pois, nítida entre o objeto e as conseqüências dos direitos reais e obrigacionais. Daí não se segue, 
porém, sejam ambos incomunicáveis. Pelo contrário: antes de mais nada, junto aliás, neste ponto, com os direitos sucessórios, ambos são patrimoniais, isto é, susceptíveis de avaliação em dinheiro (interêsse econômico) ao contrário dos direitos de Família, cujo interêsse é predominantemente moral.

Em segundo lugar, o direito das obrigações tende, muitas vezes, à constituição dum direito real, como sucede nos contratos de mutuo (art. 1257), compra e venda (art. 1122) e doação, por exemplo (art. 1165). Por isso as obrigações são qualificadas como "jura ad rem", isto é, como originando um direito (indirecto) à coisa, obtida mediante a realização (v.g., pela tradição) da prestação por parte do devedor. Os direitos reais, pelo contrário, chamam-se assim, pelo fato de recairem de modo direto e imediato sobre a coisa (v.g. direito de propriedade, art. 524; direito de servidão predial, art. 695; direito de enfiteuse, art. 678), prescindindo, para seu exercício, da cooperação de quem quer que seja ("Jura in re", "jura erga omnes").

Os direitos reais, por outro lado, podem ser constituidos mediante pactos e estipulações, isto é, contratos: uma servidão, por exemplo, direito real sobre coisas alheias (art. 674) pode, em Direito Romano, constituir-se "pactionibus et stipulationibus". Ora, pelo contrato, o dono do prédio serviente "fica obrigado a tolerar que dele se utilize, para certo fim, o dono do prédio dominante" (art. 695). Assume em outras palavras, obrigação negativa de "pati", isto é, sofrer e tolerar, não impedir o exercício do direito pelo titular. Esste é o primeiro "momento", por assim dizer (obrigacional), da constituição da servidão. Como direito real, porém ("jus in re") ela se adquire só pela transcrição dos títulos no registro d' imóveis, (art. 676) transcrição essa constituindo em Direito Romano, caso de tradição simbólica (traditio instrumentorum" - C. Com., art. 200). Ora, a tradição é modo próprio de aquisição da propriedade e de direitos reais (art. 620; 675 e 676). Logo, o pacto 
cria para o proprietário do prédio serviente a obrigação de não impedir o exercicio do direito real pelo tilular, o qual, por sua vêz, só o adquire efetivamente pela quasi tradição (G. 2,31; C.C., art. 493, I).

A "locatio conductio rerum" (locação e condução de coisas, art. 1188), é contrato, como sabemos, gerando tão só obrigações entre as partes. Mas, a lei do inquilinato, em vigor no Brasil, dá ao inquilino, apesar de mero locatário, direito análogo ao real pois enquanto pagar o aluguel ele não será adstrito a respeitar o prazo do contrato o qual, por força de lei, pode durar indefinidamente, transmitindo-se, também com as mesmas características, aos herdeiros do inquilino! Além disso, a regra romana "emptio tollit locatum" (art. 1197) não se aplica mais ao inquilino, o qual, cumprindo o contrato pode afirmar seus direitos tanto contra o locador como contra terceiros. Seu direito torna-se quasi "erga omnes", assumindo caráter de verdadeiro direito real, embora na essência seja de natureza obrigacional. Através esse exemplo de nossa prática jurídica vemos, portanto, o valor relativo da distinção entre direitos reais e obrigacionais a qual, por outro lado, é predominante.

Outras diferenças entre Direitos Obrigacionais e Reais são apontadas pelos Autores, dentre os quais Clovis, em seu esplêndido Direito das Obrigações, 1 vol., 9. ${ }^{\text {a }}$ ed., Rio 1957, $\S 5 .^{\circ}$. Assim, os direitos reais seriam por natureza inconsumiveis pondendo exercer-se indefinidamente no tempo, caso recaiam, como é possível sobre coisas inconsumiveis. Na hipótese contrária, (CC., art. 51) o direito se extingue por falta de objeto (como, por exemplo o pão - coisa consumível - objeto de meu direito de propriedade) e não pelo fato de seu exercício. O direito obrigacional, pelo contrário, cria uma relação de direito por essência transitória entre as pessoas: alugo meu cavalo por seis meses, digamos. Durante o decurso do prazo vai-se esgotando aos poucos, pelo exercício, o direito do loca- 
tário, ao uso do animal, até expirar, findo o prazo, mas o direito de propriedade, durante esse tempo, do locador nenhuma alteração sofre. Outro exemplo: não posso cobrar mais duma vez uma dívida (art. 1531 C.C.).

Além disso, para alguns, os direitos obrigacionais seriam relativos enquanto exercitáveis só contra pessoas determinadas (os devedores) e os reais absolutos enquanto oponíveis "erga omnes" (v. g., a definição, já citada, do direito de propriedade, contida no art. 524 de nosso CG). Os direitos reais, além da propriedade, são pouco numerosos (art. 674, n.os I a IX) enquanto as obrigações variam consideravelmente, segundo as circunstâncias, não comportando enumeração taxativa, muito embora sejam exigiveis só na forma da lei, segundo a definição romana já analisada ("secundum nostrae civitatis jura").

Considerando, em sua essência, o vínculo, obrigacional, passemos ao estudo da prestação, nome dado à obrigação do devedor. Etimologicamente o termo vem de "praes, praedis" e "stare" estar. Segundo alguns romanistas no mais antigo processo romano, (das "legis actiones" ou das "ações da lei") desenvolvendo-se oralmente, os litigantes iam a juízo acompanhados de testemunhas, servindo, também estas, de fiadores ("praedes") do comparecimento das partes aos sucessivos atos processuais até à "sententia". O fiador "praestal", isto é, responde, pelo pagamento da multa estipulada, caso a parte viole a promessa, deixando de comparecer no dia marcado. Ultrapassando, mais tarde, o âmbito dos tribunais, o termo "prestação" passou a indicar a obrigação do devedor, oriunda de qualquer causa, incluindo a idéia de responsabilidade, isto é, de afirmação contra ele, das conseqüências patrimoniais da obrigação assumida (CC art. 159; art. 1056).

No sentido indicado o termo ocorre inúmeras vezes em nosso Código Civil.

Quanto à prestação, as obrigações podem ser: I. Genéricas, II. Alternativas e III. Facultativas, IV Divisiveis e 
1ndivisíveis. Obrigações Genéricas (de dar coisa incerta) - (arts. 874-77), são aquelas tendo por objeto "res quae pondere, numero mensurave consistunt", segundo a linguagem de GaIo $(3,90 ; 2,196 ; 3,175)$ e que "comumente se recebem contando, pesando, medindo ou assinalando" diz o $\S 10^{\circ}$ do art. 1127 do C. Civil bras. Dessa natureza são as coisas chamadas "fungíveis" (art. 50), caracterizadas pela possibilidade de se substituirem umas pelas outras, da mesma espécie (v. g.: arroz) qualidade (de primeira) e quantidade (50 quilos, digamos).

O mutuo tem por objeto coisas genéricas e fungíveis (arts. 1256, 1262, 1264, III); o dote pode recair sobre bens fungíveis ou não (art. 311); o usufruto chamado irregular recai sobre coisas fungíveis (arts. 719, 720, 722, 726). Também o penhor pode ter por objeto coisa fungível (art. 770); há um depósito irregular quando as coisas guardadas são fungíveis. Em tal caso, aliás, aplicam-se ao depósito as regras do mutuo (art. 1286). No contrato de sociedade, finalmente, a entrada pode consistir em coisas fungiveis (art. 1378), correndo os riscos delas por conta da sociedade (art. 1.390, $\S 1 .^{\circ}$ ). Em todos esses casos o devedor paga restituindo ao credor o equivalente ("tantundem") das coisas recebidas, isto é, dando-lhe outras coisas do mesmo gênero, qualidade e quantidade, como acontece no mutuo (art. 1.256).

Conseqüência importante do caráter genérico da prestação é a regra "genus non perit": a responsabilidade subsiste a cargo do devedor de coisas fungíveis mesmo quando elas perecem, para êle, em conseqüência de caso fortuito ou de força maior (art. 1.058 e $\S$ único). Sou assaltado, por exemplo, ao sair da casa do meu amigo, o qual me deu quinhentos cruzeiros novos em dinheiro de contado, a título de mutuo. Perco para o ladrão a quantia, em conseqüência de fato necessário cujos efeitos, nas circunstancias, eu não podia evitar nem impedir, para usarmos a linguagem do $\S$ un. do art. 1.058 do C. Civil. Con- 
tinuo devedor da quantia pois sou obrigado a restituir ao mutuante soma equivalente ("tantundem") àquela e não as mesmas espécies recebidas. Ora, o dinheiro em circulação não pode, em princípio, extinguir-se, ficando, portanto, intacta minha responsabilidade. $O$ contrário aconteceria si, tratando-se de comodato (art. 1.248 e ss.) sofresse eu o mesmo assalto, levando o ladrão consigo o relógio de ouro, contendo, digamos, as iniciais do avô de meu amigo e possuindo, por isso, valor de afeiçâo (art. 1.543 do C.C.); semelhante relógio, insubstituível, constitui verdadeira species tornando-se impossível encontrar equivalente dele: a obrigação do devedor extingue-se em tal caso de perecimento fortuito da coisa não fungivel ("Res perit domino").

\section{Bibliografia}

Albertário, Studi di Diritto Romano, III, Le Obbligazioni, Milão, 1936. ARNDST, L., Lehrbuch der Pandekten, 13.a ed., Stuttgart, 1886, Obrigafões, pp. 379-760.

Arguello, Peña Guzman, Derecho Romano, B. Aires, 1966; Vêr o tomo Segundo, contendo a exposição das “obrigações”, pp. 171-423.

ARIAS-RAMos, Obligaciones, in Manual de Derecho Romano, 2 vols., Madrid, 5. a ed., 1951 - (fuentes, garantia, cesión y extinción), pp. 521-619.

BETTI, La struttura dell' obbligazione Romana e il problema della sua genesi, 1 vol., Milão, 1955.

Betri, Istituzioni di Diritto Romano, vol. 2., 1. a Parte, Padua, 1962, Obrigações.

Bevilaqua, Clovis, Obrigações, 1 vol., 9. ${ }^{a}$ ed., Livr. Fco. Alves, 1957. BoNfaNTE, Instituciones de Derecho Romano, 1 vol., Madrid, 1965, Obrigações, §§ 117 e ss., pp. 375-546.

NoTA

Os arts. citados são do C.C. bras.

G. = GAIO, Comentários

C. Com. = Código Comercial brasileiro 
BoNFANTE, Scritti Giuridici varì, n. 3, Obbligazioni e principii generali, Turim, 1916-1925, 4 vols.

BONGEAN, Explication méthodique des Institutes de Justinien, 2 vols., Paris, 1880. Vêr o tomo segundo, contendo a exposição das "Obrigações", pp. 208-645.

BRUGI, Istituzioni di Diritto Romano (Diritto privato Giustinianea), 3.a ed., Turim, 1926, "Obbligazioni", pp. 274-446.

BUCKLAND, Mc NAIR, Roman Law and Common Law, A comparison in Outline", 1 vol., Cambridge, 1952, "Obligations", pp. 193-395.

BUCKLAND, W. W., A text-book of Roman Law from Augustus to Justinian, 1 vol., 2..$^{\text {e }}$ ed, Cambridge, 1932, “Obrigações”, pp. 405-527.

Carvalho de Mendonça, Manoel Inacio, Contratos no Direito Civil Brasileiro, 2 vols., 1911, R. Janeiro.

CAES, L.-HENRION, R., Collectio Bibliographica Operum ad Jus Romanum Pertinentium, 5 vols., Bruxelas, "Office International de Librarie", 1949-1956. As referências bibliográficas ao direito romano das Obrigações acham-se em todos os volumes da "Collectio".

Collinet, Obligations (Droit Romain), 1 vol., Paris, 1928.

CORNIL, Droit Romain, Traité élémentaire de droits réels et obligations, 1 vol., 1885.

CORNIOLEY, P., Naturalis Obligatio, Éssai sur l' origine et l' évolution de la notion en Droit Romain, Genève, 1964.

DeRNBurg, HEINRICH, Geschichte und Theorie der Kompensation nach Roemischem und neuerem Rechte, mit Besonderer Ruecksicht auf die Preussische und Franzoesische Gesetzgebung, Reedição da 2.a ed., de 1868, Scientia Verlag Aalen, 1965.

1)UвoIs, E., Programme du cours de droit romain, Obligations, Cotillon, 1871.

Ferrinir, C., Manuale di Pandette, 4. ${ }^{a}$ ed., 1 vol., Milão, 1953, v. pp. 407-586.

FERRo-Caramês, J. M., Curso de Derecho privado romano (De las obligaciones y sus fuentes), 5. ${ }^{\mathbf{a}}$ ed., B. Aires, 1949.

FRANCESCHeli, R, Ra garanzia reale delle obbligazioni nel diritto romano classico e nel diritto inglese (Fiducia cum creditore $e$ "Mortgage). in "Studi Albertoni", 1 vol., Pádua, pp. 515-562, 1938.

De Fresquet, Traité élèmentaire de Droit Romain, 2 vols., Paris, s.d. Obrigações: v. pp. 58-383. 
Garsonnet, Textes de Droit Romain, 1 vol., Paris, 1888, "Droits de Créance", pp. 131-330.

Giffard, A. E., Précis de Droit Romain, 3.a ed., 2 vols., Paris, Dalioz, 1938. V. tomo segundo: Obligations.

GIFFARD-VILLERS, Droit romain et ancien droit français: las obligations, Paris, Dalloz, 1958.

GIRARD, PAUL FRÉDÉRIC, Manuel k̂lémentaire de Droit Romain, 1 vol., 8. ${ }^{a}$ ed., Paris, 1929. V. pp. 415, 840.

IgLesias, JUAN, Derecho Romano, Instituciones de Derecho Privado, 2. ${ }^{\mathrm{a}}$ ed., 2 vols. ediciones Ariel, Barcelona, 1953. Sôbre Obrigações, v. vol. 2 , pp. 1-189.

JAMES, PhILIP, Introduction to English Law, 5. ${ }^{\text {a }}$ ed., Londres, 1962, "The Law of Contract", pp. 231-288 — "The Law of torts", pp. 292-342.

JoLowICZ, H. F., Historical Introduction to the study of Roman Law, 2. ${ }^{a}$ ed., 1952, Cambridge, 1 vol., vêr pp. 161-175; 284-313 (Obrigações).

JöRS-KUNKEL, Römisches Privatrecht, 1 vol., Heidelberg, $19493 .^{\mathrm{a}}$ ed., 4. ${ }^{\text {a }}$ Parte, Forderungsrechte, pp. 163-269 (Trad. espanhola de L. Prieto Castro, 1 vol, Labor, Madrid, 1937).

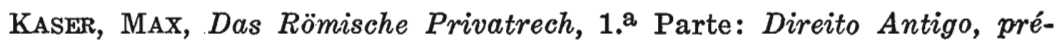
clássico e clássico, 1 vol., Munique, 1955. (Ver §§ 8-9; 39-45; 112-156 - Obrigações). Acrescentar: 2. ${ }^{\mathrm{a}}$ Parte Die nachklassischen Entwicklungen", 1 vol., Munique, 1959. V. §§ 253-333 (Obrigações).

LEE, R. W., The elements of Roman Law, with a translation of the Institutes of Justinian, 1 vol., Londres, 1946. Vêr pp. 283-411.

LEHR, ERNest, Élements de Droit Civil Anglais, 1 vol., Paris, 1885, Obrigações, pp. 468-648.

IEPONTE-MONIER, Les obligations en droit romain et dans l' ancien droit français, Paris, Sirey, 1954.

Marezoll-Pellat, Précis d'un cours sur l' ensemble du Droit Privé des Romains, 1 vol., Paris, 1852, Obrigações, pp. 313-414.

MARGAdANT, S. GUILHERMo F., El derecho priv. Romano como introduccion a la cultura juridica contemporanea, 1 vol., $3 .{ }^{a}$ ed., México, 1968, pp. 295 437, (Obrigações).

Di Marzo, SALvatore, Le Basi Romanistiche del Codice Civile, 1 vol., Turim, 1950, Livro $4 .^{\circ}$, Das Obrigações, pp. 211-332.

Di Marzo, Salvatore, Istituzioni di Diritto Romano, 1 vol., Milão, 1946, 5. ${ }^{\text {a }}$ ed., pp. 299-424.

Massonní, De la Confusion dans les Obligations, Aix, 1890, (tese). 
MAYNz, Traité des Obligations d'aprés le droit romain, 1 vol,, 18ä0, Bruxelles.

MEIRA, Silvio A. B., Instituições de Direito Romano, 1 vol., $3 .^{\mathrm{a}}$ ed., Max Limonad, São Paulo, 1968, Direito das Obrigações, pp. 307435.

MoLitor, Les obligations en Droit Romain, 2 vols., Paris, 1851-53.

MONIER, RAYMOND, La garantie contre les vices cachés dans la vente romaine, Paris, Sirey, 1930.

MonIER, RAYMond, Manuel de Droit Romain, Les Obligations, tomo II, 5. ${ }^{\mathrm{a}}$ ed., Paris, 1954.

MONTES, ANGE CRISTOBAL, Curso de derecho romano (Obligaciones), Venezuela, 1964, 1 vol., pp. 791.

MoYLE, J. B., Imperatoris Justianiani Institutionum Libri Quattusr, with Introduction, Commentary and Excursus, 1 vol., $5 .^{\mathrm{a}} \mathrm{ed}$., Oxford, 1931, pp. 391-542 (Obrigações).

ORTOLAN, Histoire de la législation romaine, depuis son origine jusqu' à la législation moderne et généralisation du Droit Romain, 2. ${ }^{\text {a }}$ ed, 3 vols., Paris, 1876. V. Obrigações, vol. III, pp. 128-471.

PASTorr, Franco, Profilo Dogmatico e storico delle obbligazioni romane, Varese, Cisalpino, 1951, $325 \mathrm{pp}$.

POTHIER, Tratado das Obrigą̧̃es Pessoais e Recíprocas (Trad. de Corrêa Telles), 2 vols., Garnier, 1806.

RADIN, MAX, Handbook of Roman Law, 1 vol., St. Paul Minnesota, 1927, pp. 121-329 (Obrigações).

REIN, WILHELM, Privatrecht und Zivilprozess der Roemer, von der aeltesten Zeit bis auf Justinian, Reedição da 2. a edição de Leipzig de 1858, Scientia Verlag Aalen, 1964, Obrigações: pp. 607-771.

RoBY, HENRY, JoHN, Roman Private Law in the times of Cicero and of the Antonines, 2 vols., Cambridge, 1902. Vêr vol., segundo, contendo as Obrigações (pp. 2-310).

RuIZ, RAFAFL Derecho Romano, II (Obligaciones), Caracas; s.d.

SARFATTI, MARIo, Influenza reciproca del Diritto Romano e del diritto Anglosassone in "Studi Albertoni", 1 vol., Pádua, 1938, pp. 563575.

SavignY, Le Droit des Obligations, Trad. Gérardin, $2 .^{\mathrm{a}}$ ed., 2 vols., Paris, 1873.

SENN, FÉLIX, Le "nexum, Contrat de prêt du trés ancien droit romain, Paris, Larose, 1905.

SENN, FÉLIX, Clauses insérées dans les ventos d' esclaves, Paris, 1888, 59 pp., Grandin. 
Schulz, Fritz, Classical Roman Law, 1 vol., Oxford, 1954. Vêr pp. 455-645. (Obrigações). Trad. espanhola de Santa Cruz Treijeiro, Derecho Romano Classico, 1 vol., Barcelona, 1960. Vêr pp. 435607 (Obrigações).

TOLA, FBRNANDo, Derecho romano: obligaciones, contratos, delitos $y$ acciones, Lima, 1948.

VermoNd, EDMOND, De jure obligationum, Paris, 1937, 2 vols., Crandin.

VERNET, P., Textes choises sur la théorie des obligations en droit romain, Paris, Durand, 1865.

Vocr, Pasquale, Le obbligazioni romane (corso di Pandette) Il Contenuto dell' obbligatio, 1 vol., Milão, 1969.

VAN WeTter, Pandectes, Les Obligations, tomo 3, 1. a Parte, tomo $4 .^{\circ}$ (2. a Parte), 2 vols., Paris, 1910.

Windscheid, Pandekten, §§ 250 e ss., Frankfurt, 1906.

ZULUETA, F. DE, The Roman Law of Sale, Introduction and Select Texts, 1 vol., Oxford, 1957. 